\title{
Effect of whey protein isolate on rehydration after exercise
}

\author{
Lewis J. James ${ }^{1}$, Lewis Mattin ${ }^{2}$, Peter Aldiss ${ }^{2}$, Rukayat Adebisi ${ }^{2}$ and Ruth M. Hobson ${ }^{2}$ \\ ${ }^{1}$ School of Sport, Exercise and Health Sciences, Loughborough University, UK and ${ }^{2}$ School of Science and Technology, \\ Nottingham Trent University, Nottingham, UK
}

Post-exercise rehydration has been well studied, but there is little information regarding the effect of protein. We recently reported that when added in an energy matched fashion and when drinks are ingested in a volume equivalent to $150 \%$ sweat loss, addition of milk protein $^{(1)}$ to a carbohydrate-electrolyte drink enhances rehydration, whilst the addition of whey protein isolate does not ${ }^{(2)}$. In contrast, Seifert et al.$^{(3)}$ reported that when a volume of $100 \%$ sweat loss is ingested, the addition of whey protein to a carbohydrate-electrolyte drink in a non-energy matched fashion enhances rehydration. These studies have only examined the effect of protein addition to carbohydrate-electrolyte drinks and thus the purpose of the present study was to determine if whey protein effects rehydration in isolation with a rehydration volume sufficient to fully restore fluid balance after exercise (150\% sweat loss).

After ethical approval, ten subjects (7 male, 3 female; age: 22 (2); weight: 70.58 (10.03) kg; height: 1.71 (0.12) m) completed a familiarisation and two experimental trials. For each trial, subjects lost $\sim 2 \%$ of their body mass via intermittent cycling (137 (23) W) in the heat $\left(35^{\circ} \mathrm{C}, 60 \%\right.$ relative humidity). Subjects then rehydrated with $150 \%$ of their body mass loss over $1 \mathrm{~h}$. During rehydration subjects ingested bottled mineral water $(\mathrm{W})$ or mineral water $+20 \mathrm{~g} . \mathrm{l}^{-1}$ whey protein isolate (WP) in a double blind randomised, counterbalanced order. After drinking, subjects rested in the laboratory for $4 \mathrm{~h}$. Urine and blood samples were taken pre-exercise, post-exercise, postdrinking and $1 \mathrm{~h}, 2 \mathrm{~h}, 3 \mathrm{~h}$ and $4 \mathrm{~h}$ post-drinking.

The total volume of urine produced after drinking was not different between trials (W: $1234(358) \mathrm{ml}$; WP: 1306 (268) ml; $P=0.409)$, with $40(14) \%(\mathrm{~W})$ and $37(14) \%(\mathrm{WP})$ of the drinks retained $(P=0.322)$. Net fluid balance, which was calculated from sweat loss during exercise, urine production and drink ingestion was not different between trials $(P=0.792)$ and at the end of the study period was $-605(318) \mathrm{ml}(\mathrm{W})$ and $-660(274) \mathrm{ml}(\mathrm{WP})$. Urine and serum osmolality response was not different between trials $(P>0.05)$. Compared to pre-exercise, plasma albumin content was increased from $1 \mathrm{~h}$ onwards during WP $(P<0.05)$, but did not change during W. In line with this, plasma volume was greater at $3 \mathrm{~h}$ and $4 \mathrm{~h}$ during WP compared to $\mathrm{W}(P<0.05)$.

These results suggest that when ingested in a volume equivalent to $150 \%$ of sweat loss, the addition of 20 g. $1^{-1}$ whey protein isolate to mineral water neither enhanced nor inhibited the rehydration process. Whilst protein ingestion increased plasma albumin content, which was likely responsible for the increase in plasma volume $3-4 \mathrm{~h}$ post-drinking in WP, it appears that this increased oncotic pressure was not sufficient to reduce the diuresis associated with ingesting a large volume of drink in a short time period. Post-exercise nutritional requirements are often multifactorial (rehydration, glycogen resynthesis, muscle protein synthesis) and the present data demonstrates that when post-exercise protein intake might benefit recovery or adaptation, this can be achieved without compromising rehydration.

1. James LJ, Clayton D \& Evans GE (2011) Effect of milk protein addition to a carbohydrate-electrolyte rehydration solution ingested after exercise in the heat. Br J Nutr 105, 393-399.

2. James LJ, Gingell R \& Evans GH (2012) Effect of whey protein addition to a carbohydrate-electrolyte rehydration solution ingested after exercise in the heat. J Athl Train 47, 61-66.

3. Seifert J, Harmon J \& DeClercq P (2006) Protein added to a sports drink improves fluid retention. Int J Sport Nutr Exerc Metab 16, 420-429. 